\title{
Isolasi dan Identifikasi Bakteri Streptococcus spp. pada Babi Penderita Porcine Respiratory Disease Complex
}

\section{(ISOLATION AND IDENTIFICATION OF STREPTOCOCCUS SPP. IN PIGS WITH PORCINE RESPIRATORY DISEASE COMPLEX)}

\author{
Ni Kadek Meita Swandewi ${ }^{1 *}$, I Gusti Ketut Suarjana ${ }^{2}$, I Nengah Kerta Besung ${ }^{2}$, \\ ${ }^{1}$ Mahasiswa Program Sarjana Kedokteran Hewan, Fakultas Kedokteran Hewan, Universitas \\ Udayana, Jl. PB. Sudirman, Denpasar, Bali; ${ }^{2}$ Laboratorium Bakteriologi dan Mikologi \\ Fakultas Kedokteran Hewan, Universitas Udayana, Jl. PB. Sudirman, Denpasar, Bali. \\ *Email: meita.swandewi@gmail.com
}

\begin{abstract}
Abstrak
Streptococcus sp. merupakan salah satu penyebab primer terjadinya Porcine Respiratory Disease Complex (PRDC). Penelitian ini dilakukan untuk mendeteksi bakteri Streptococcus sp. di saluran pernapasan babi penderita PRDC serta distribusi bakteri Streptococcus sp. pada babi pra sapih dan pasca sapih. Sebanyak 43 sampel swab rongga hidung dikumpulkan dari babi yang menunjukkan gejala penyakit PRDC seperti depresi, anorexia, dyspnea, adanya eksudat dari rongga hidung, batuk/bersin, dan pembengkakan pada persendian. Sampel berasal dari peternakan babi di kabupaten Tabanan, kabupaten Badung, dan kabupaten Gianyar. Semua sampel ditanam pada media sheep blood agar dilanjutkan dengan uji pewarnaan Gram. Koloni yang dicurigai kemudian dilakukan uji primer berupa uji katalase dan uji oksidase serta uji biokimia dengan MRPV, TSIA, SIM, uji koagulase dan uji gula gula . Hasil penelitian menunjukkan 23 sampel (tiga belas dari babi pra sapih dan sepuluh dari babi pasca sapih) telah terdeteksi positif Streptococcus $s p$. $\alpha$ hemolitik (20 isolat) dan Streptococcus $s p . \beta$ hemolitik (3 isolat).
\end{abstract}

Kata kunci: babi; PRDC; Steptococcus spp.; swab rongga hidung

\begin{abstract}
Streptococcus sp. is one of the primary causes of the Porcine Respiratory Disease Complex (PRDC). This research was conducted to study the bacteria Streptococcus sp. in the pig's respiratory tract sufferers Porcine Respiratory Disease Complex (PRDC) and distribution of the bacteria Streptococcus sp. in pre-weaned and post-weaned pigs. A total of 43 samples were nasal swab taken from pigs that showed PRDC symptoms such as depression, anorexia, dyspnea, the presence of exudates from the nasal, coughing / sneezing, and swelling of the joints. Samples were received from pig farms in Tabanan regency, Badung regency, and Gianyar regency. All samples were planted on sheep media so that blood was continued with the Gram staining test. The suspected colonies were then subjected to a primary test consisting of catalase and oxidase tests as well as biochemical tests with MRPV, TSIA, SIM, coagulase test and sugar test. The results showed that 23 samples (thirteen from pre-weaned pigs and ten from post-weaning pigs) were tested positive for Streptococcus sp. hemolytic $\alpha$ (20 isolates) and Streptococcus sp. hemolytic $\beta$ ( 3 isolates).
\end{abstract}

Keywords: pigs; PRDC; Steptococcus spp.; nasal swab

\section{PENDAHULUAN}

Ternak babi masih mempunyai peranan yang sangat penting dalam menunjang ekonomi masyarakat khususnya di pedesaan (Agustina et al., 2016). Di Bali sekitar $80 \%$ rumah tangga di pedesaan memelihara ternak babi yang jumlahnya antara tiga sampai lima ekor, meskipun bersifat sambilan, namun terbukti menjadi salah satu sumber pendapatan yang sangat diandalkan oleh keluarga. Jumlah konsumsi daging babi yang meningkat setiap tahunnya berbanding terbalik dengan jumlah populasi ternak babi di Bali yang 
dari tahun ke tahun yang mengalami pasang surut. Tercatat pada tahun 2016 populasi babi yaitu 803.920 ekor angka ini sedikit meningkat dari tahun 2015 dengan 794.936 ekor dan pada tahun 2017 mengalami penurunan yang cukup signifikan dengan 682.386 ekor (Dinas Peternakan, 2018).

Saluran pernapasan merupakan tempat pertumbuhan beberapa bakteri flora normal dan suatu saat bakteri ini dapat menjadi patogen (Adi, 2014). Beberapa bakteri flora normal yang terdapat pada saluran respirasi atas pada babi seperti hidung dan tonsil diantaranya yaitu Streptococcus suis, Rothia nasimurium, lactobacillus, Streptococcus dysgalactiae, Staphylococcus hycus, Staphylococcus aureus, Arcanobacterium pyogenes, dan Actynomyces hyovaginalis. Diantara beberapa bakteri flora normal tersebut, terdapat beberapa bakteri yang berpotensi patogen pada saluran pernapasan babi diantaranya yaitu Streptococcus suis, Streptococcus dysgalactiae, dan Staphylococcus aureus (Baele et al., 2001).

Pada saat ini salah satu penyakit pada saluran pernapasan pada babi yang memiliki dampak yang cukup besar adalah Porcine Respiratory Disease Complex (PRDC) yang disebabkan oleh infeksi berbagai patogen virus dan bakteri. Bakteri utama penyebab PRDC ini adalah Actinobacillus pleuropneumoniae, Streptococcus Suis, Pasteurella multocida, Bordetella bronchiseptica, Haemophilus parasuis, dan Mycoplasma hyopneumoniae (Opriessnig et al., 2011). Virus patogen yang menyebabkan terjadinya PRDC adalah porcine reproductive and respiratory syndrome virus (PRRSV), Swine Influenza, dan porcine circovirus type 2 (PCV2), Pseudorabies virus, Paramyxoviruses (PMV), Torque teno sus virus (TTSuV), Porcine Respiratory Coronavirus (PRCV), dan Porcine cytomegalovirus (PCMV) (Opriessnig et $a l ., 2011)$. Tanda klinis yang umum terjadi pada penderita PRDC adalah depresi, anorexia, dyspnea, disertai dengan adanya eksudat dari rongga hidung, batuk kering yang bersifat sporadic menandakan keterlibatan infeksi mycoplasma (Ross, 1999), batuk basah yang bersifat paroksimal menandakan keterlibatan virus influenza (Halbur, 1997). Keterlibatan bakteri Streptococcus suis pada PRDC dapat menyebabkan berbagai infeksi pada babi diantaranya adalah meningitis, pneumonia, septicemia, bronkopneumonia, polyarthritis, dan polyserositis (Del'Arco et al., 2008).

Kejadian PRDC di Bali masih belum pernah di laporkan secara pasti, demikian pula dengan laporan agen penyebab PRDC oleh bakteri Streptococcus spp. beserta distribusi bakteri Streptococcus sp. terhadap babi penderita PRDC yang di kelompokkan berdasarkan kelompok umur masih sangat minim, sehingga penelitian ini sangat penting di lakukan.

\section{METODE PENELITIAN}

\section{Sampel Penelitian}

Sampel penelitian yang digunakan adalah swab rongga hidung babi penderita PRDC yang diambil dari kabupaten Badung, Tabanan, dan Gianyar. Sampel diambil secara aseptis kemudian disimpan dalam tabung Eppendorf yang di dalamnya sudah berisi struart transport medium (oxoid).

\section{Isolasi Bakteri}

Isolasi bakteri dilakukan pada Sheep Blood agar, kemudian diinkubasi pada suhu $37^{\circ} \mathrm{C}$ selama $18-24$ jam. Setelah itu identifikasi koloni yang tumbuh meliputi bentuk, warna, tepian, dan diameter (Toelle et al., 2014).

\section{Identifikasi Bakteri}

Identifikasi bakteri yang di lakukan meliputi pengamatan makroskopis koloni pada media Sheep Blood agar. Setelah itu dilakukan pewarnaan Gram kemudian dilanjutkan dengan uji primer (uji katalase dan uji oksidase), uji biokimia (uji koagulase, SIM, TSIA, SCA, dan uji MR), serta uji gula - gula (glukosa, manitol, 
laktosa, dextrosa, dan sukrosa) (Carter dan Cole, 1990).

\section{Analisis Data}

Data dianalisis secara deskriptif dengan menjabarkan jumlah sampel positif Streptococcus spp. yang diisolasi dari saluran pernapasan atas pada babi klinis PRDC dan distribusinya pada kelompok umur muda (sebelum dan setelah di sapih) dan dewasa menggunakan analisis Chisquare.

\section{HASIL DAN PEMBAHASAN}

\section{Hasil}

Sampel berupa swab rongga hidung babi yang berjumlah 43 sampel (16 ekor babi pra sapih dan 27 ekor babi pasca sapih) yang di ambil dari kabupaten Tabanan, kabupaten Badung, dan kabupaten Giayar di isolasi pada media Sheep Blood agar dan di lanjutkan dengan pewarnaan Gram. Dari 43 isolat yang di isolasi pada media Sheep Blood agar serta pewarnaan Gram hanya di temukan 23 isolat yang dicurigai merupakan Streptococcus spp. dengan hasil pewarnaan Gram bakteri berwarna ungu berbentuk bulat yang membentuk rantai panjang, pendek, serta berpasangan. Hasil isolasi 23 isolat bakteri yang di curigai Streptococcus spp. pada media Sheep Blood agar dapat dijelaskan pada tabel 1. Hasil isolasi bakteri dari sampel swab rongga hidung babi pra sapih dan pasca sapih penderita PRDC pada Sheep Blood agar yang dicurigai merupakan Streptococcus sp. menunjukkan koloni berbentuk bulat, permukaan cembung, kecil, tepi rata, berwarna putih keabuan dengan diameter 1 - $3 \mathrm{~mm}$, terdapat $\alpha$ hemolisis di sekeliling koloni pada isolat B1, B2, B3, B5, B6, B7, B8, B9, B10, T1, T7, T8, T10, T18, G5, G6, G7, G9, G10 dan G11 serta terdapat $\beta$ hemolisis di sekeliling koloni isolat T3, T9, dan T11. Hasil tersebut sesuai dengan literatur Carter dan Cole (1990) yang menyatakan bahwa koloni bakteri Streptococcus sp. yang tumbuh pada media Blood Agar adalah kecil, putih keabuabuan, mukoid, halus, berbentuk bulat dan menunjukkan alfa, beta, dan gamma hemolisa pada media.

Setelah di isolasi dan identifikasi secara makroskopis pada Sheep Blood agar dan secara mikroskopis pada pewarnaan Gram selanjutnya 23 isolat tersebut di uji menggunakan uji primer berupa uji katalase dan uji oksidase. Pada 23 isolat menunjukan hasil negatif pada uji katalase dan uji oksidase. Hasil ini sesuai dengan literatur Carter and Cole (1990), yang menyatakan hasil uji katalase bakteri Streptococcus spp. negatif dan uji oksidase negatif.

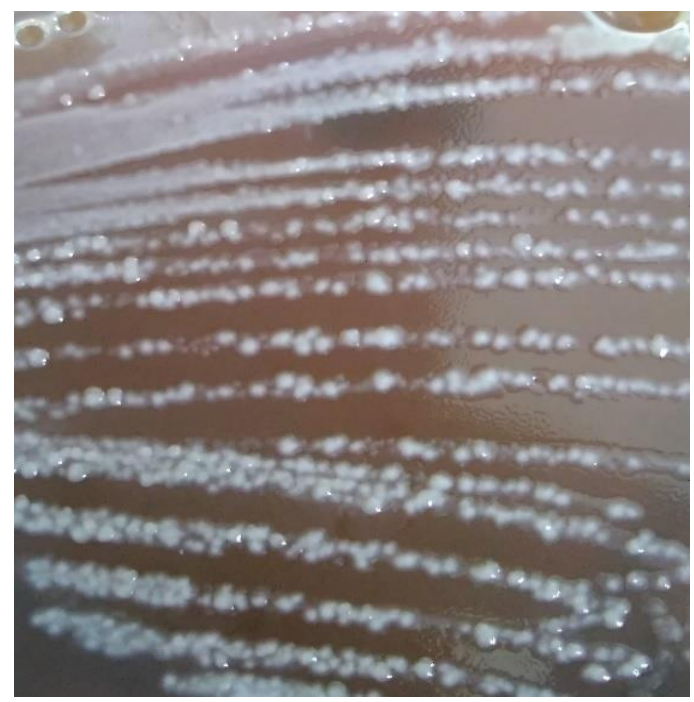

Gambar 1. Koloni bakteri yang tumbuh pada Sheep Blood agar. 
Tabel 1. Hasil Isolasi Bakteri dari Sampel Swab Rongga Hidung Babi Pra Sapih dan Pasca Sapih Penderita PRDC pada Sheep Blood agar

\begin{tabular}{|c|c|c|c|c|c|c|c|}
\hline \multirow[b]{2}{*}{ No } & \multirow[b]{2}{*}{$\begin{array}{c}\text { Kolo } \\
\text { ni }\end{array}$} & \multicolumn{6}{|c|}{ Morfologi } \\
\hline & & Bentuk & Tepi & Permukaan & Warna & Diameter & $\begin{array}{c}\text { Kemampuan } \\
\text { Hemolisis }\end{array}$ \\
\hline 1. & B1 & Halus & Rata & Cembung & $\begin{array}{c}\text { Putih } \\
\text { keabuan }\end{array}$ & $1-3 \mathrm{~mm}$ & $\alpha$ hemolitik \\
\hline 2. & B2 & Halus & Rata & Cembung & $\begin{array}{c}\text { Putih } \\
\text { keabuan }\end{array}$ & $1-3 \mathrm{~mm}$ & $\alpha$ hemolitik \\
\hline 3. & B3 & Halus & Rata & Cembung & $\begin{array}{c}\text { Putih } \\
\text { keabuan }\end{array}$ & $1-3 \mathrm{~mm}$ & $\alpha$ hemolitik \\
\hline 4. & B5 & Halus & Rata & Cembung & $\begin{array}{c}\text { Putih } \\
\text { keabuan }\end{array}$ & $1-3 \mathrm{~mm}$ & $\alpha$ hemolitik \\
\hline 5. & B6 & Halus & Rata & Cembung & $\begin{array}{c}\text { Putih } \\
\text { keabuan }\end{array}$ & $1-3 \mathrm{~mm}$ & $\alpha$ hemolitik \\
\hline 6. & B7 & Halus & Rata & Cembung & $\begin{array}{c}\text { Putih } \\
\text { keabuan }\end{array}$ & $1-3 \mathrm{~mm}$ & $\alpha$ hemolitik \\
\hline 7. & B8 & Halus & Rata & Cembung & $\begin{array}{c}\text { Putih } \\
\text { keabuan }\end{array}$ & $1-3 \mathrm{~mm}$ & $\alpha$ hemolitik \\
\hline 8. & B9 & Halus & Rata & Cembung & $\begin{array}{c}\text { Putih } \\
\text { keabuan }\end{array}$ & $1-3 \mathrm{~mm}$ & $\alpha$ hemolitik \\
\hline 9. & $\mathrm{~B} 10$ & Halus & Rata & Cembung & $\begin{array}{c}\text { Putih } \\
\text { Keabuan }\end{array}$ & $1-3 \mathrm{~mm}$ & $\alpha$ hemolitik \\
\hline 10. & $\mathrm{~T} 1$ & Halus & Rata & Cembung & $\begin{array}{c}\text { Putih } \\
\text { keabuan }\end{array}$ & $1-3 \mathrm{~mm}$ & $\alpha$ hemolitik \\
\hline 11. & $\mathrm{~T} 3$ & Halus & Rata & Cembung & $\begin{array}{c}\text { Putih } \\
\text { keabuan }\end{array}$ & $1-3 \mathrm{~mm}$ & $\beta$ hemolitik \\
\hline 12. & $\mathrm{~T} 7$ & Halus & Rata & Cembung & $\begin{array}{c}\text { Putih } \\
\text { keabuan }\end{array}$ & $1-3 \mathrm{~mm}$ & $\alpha$ hemolitik \\
\hline 13. & $\mathrm{~T} 8$ & Halus & Rata & Cembung & $\begin{array}{c}\text { Putih } \\
\text { keabuan }\end{array}$ & $1-3 \mathrm{~mm}$ & $\alpha$ hemolitik \\
\hline 14. & T9 & Halus & Rata & Cembung & $\begin{array}{c}\text { Putih } \\
\text { keabuan }\end{array}$ & $1-3 \mathrm{~mm}$ & $\beta$ hemolitik \\
\hline 15. & $\mathrm{~T} 10$ & Halus & Rata & Cembung & $\begin{array}{c}\text { Putih } \\
\text { keabuan }\end{array}$ & $1-3 \mathrm{~mm}$ & $\alpha$ hemolitik \\
\hline 16. & $\mathrm{~T} 11$ & Halus & Rata & Cembung & $\begin{array}{c}\text { Putih } \\
\text { keabuan }\end{array}$ & $1-3 \mathrm{~mm}$ & $\beta$ hemolitik \\
\hline 17. & $\mathrm{~T} 18$ & Halus & Rata & Cembung & $\begin{array}{c}\text { Putih } \\
\text { keabuan }\end{array}$ & $1-3 \mathrm{~mm}$ & $\alpha$ hemolitik \\
\hline 18. & G5 & Halus & Rata & Cembung & $\begin{array}{c}\text { Putih } \\
\text { keabuan }\end{array}$ & $1-3 \mathrm{~mm}$ & $\alpha$ hemolitik \\
\hline 19. & G6 & Halus & Rata & Cembung & $\begin{array}{c}\text { Putih } \\
\text { keabuan }\end{array}$ & $1-3 \mathrm{~mm}$ & $\alpha$ hemolitik \\
\hline 20. & G7 & Halus & Rata & Cembung & $\begin{array}{c}\text { Putih } \\
\text { keabuan }\end{array}$ & $1-3 \mathrm{~mm}$ & $\alpha$ hemolitik \\
\hline 21. & G9 & Halus & Rata & Cembung & $\begin{array}{c}\text { Putih } \\
\text { keabuan }\end{array}$ & $1-3 \mathrm{~mm}$ & $\alpha$ hemolitik \\
\hline 22. & G10 & Halus & Rata & Cembung & $\begin{array}{c}\text { Putih } \\
\text { keabuan }\end{array}$ & $1-3 \mathrm{~mm}$ & $\alpha$ hemolitik \\
\hline 23. & G11 & Halus & Rata & Cembung & $\begin{array}{c}\text { Putih } \\
\text { keabuan }\end{array}$ & $1-3 \mathrm{~mm}$ & $\alpha$ hemolitik \\
\hline
\end{tabular}




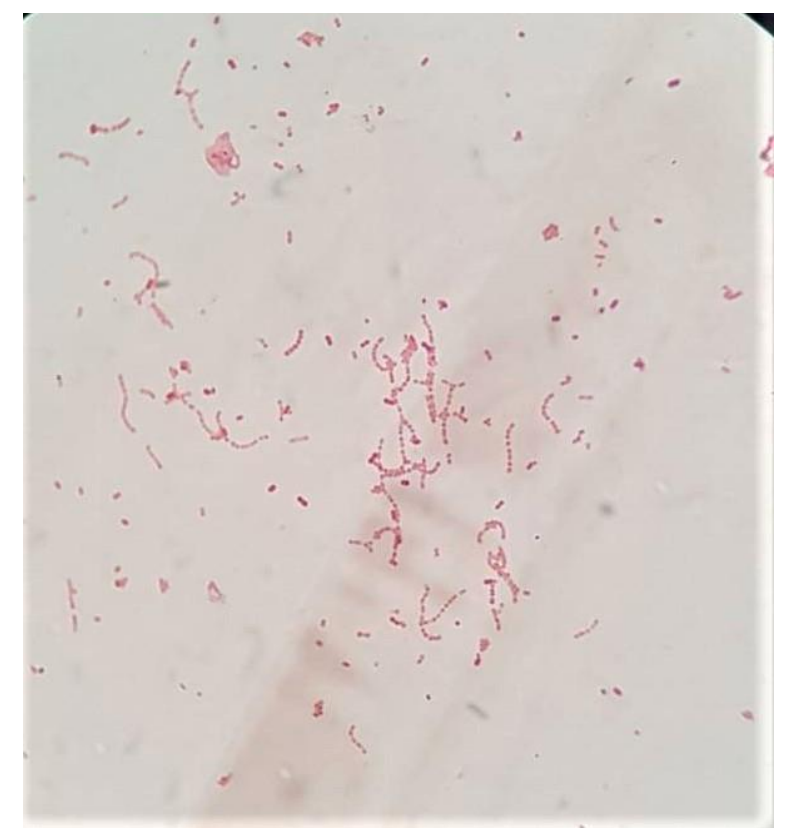

Gambar 2. Hasil pewarnaan Gram dengan perbesaran 1000x

Tabel 2. Hasil Identifikasi Bakteri dengan Uji Biokimia dan Uji Gula-gula

\begin{tabular}{|c|c|c|c|c|c|c|c|c|c|c|c|c|c|c|c|c|}
\hline \multirow[b]{2}{*}{ No } & \multirow[b]{2}{*}{ Isolat } & \multicolumn{4}{|c|}{ TSIA } & \multicolumn{3}{|c|}{ SIM } & \multirow[b]{2}{*}{ SC } & & \multicolumn{4}{|c|}{ Gula-gula } \\
\hline & & AS & $\mathbf{A B}$ & $\mathbf{H}_{2} \mathbf{S}$ & Gas & $\mathbf{S}$ & $\mathbf{I}$ & $\mathbf{M}$ & & $\begin{array}{l}\mathbf{M} \\
\mathbf{R}\end{array}$ & $\begin{array}{l}\mathbf{K} \\
\mathbf{0}\end{array}$ & Glu & Man & Lkt & Dex & Skı \\
\hline 1. & B1 & + & + & + & + & + & + & - & + & + & - & + & + & + & + & + \\
\hline 2. & B2 & + & + & + & + & + & + & - & + & + & - & + & + & + & + & + \\
\hline 3. & B3 & + & + & + & + & + & + & - & + & + & - & + & + & + & + & + \\
\hline 4. & B5 & + & + & + & + & + & + & - & + & + & - & + & + & + & + & + \\
\hline 5. & B6 & + & + & + & + & + & + & - & + & + & - & + & + & + & + & + \\
\hline 6. & B7 & + & + & + & + & + & + & - & + & + & - & + & + & + & + & + \\
\hline 7. & B8 & + & + & + & + & + & + & - & + & + & - & + & + & + & + & + \\
\hline 8. & B9 & + & + & + & + & + & + & - & + & + & - & + & + & + & + & + \\
\hline 9. & B10 & + & + & + & + & + & + & - & + & + & - & + & + & + & + & + \\
\hline 10. & $\mathrm{~T} 1$ & + & + & + & + & + & + & - & + & + & - & + & + & + & + & + \\
\hline 11. & T3 & - & + & + & - & + & + & - & + & + & - & + & + & - & + & + \\
\hline 12. & $\mathrm{~T} 7$ & + & + & + & + & + & + & - & + & + & - & + & + & + & + & + \\
\hline 13. & $\mathrm{~T} 8$ & + & + & + & + & + & + & - & + & + & - & + & + & + & + & + \\
\hline 14. & T9 & - & + & + & - & + & + & - & + & + & - & + & + & - & + & + \\
\hline 15. & $\mathrm{~T} 10$ & + & + & + & + & + & + & - & + & + & - & + & + & + & + & + \\
\hline 16. & T11 & - & + & + & + & + & + & - & + & + & - & + & + & - & + & + \\
\hline 17. & T18 & + & + & + & + & + & + & - & + & + & - & + & + & + & + & + \\
\hline 18. & G5 & + & + & + & + & + & + & - & + & + & - & + & + & + & + & + \\
\hline 19. & G6 & + & + & + & + & + & + & - & + & + & - & + & + & + & + & + \\
\hline 20. & G7 & + & + & + & + & + & + & - & + & + & - & + & + & + & + & + \\
\hline 21. & G9 & + & + & + & + & + & + & - & + & + & - & + & + & + & + & + \\
\hline 22. & G10 & + & + & + & + & + & + & - & + & + & - & + & + & + & + & + \\
\hline 23. & G11 & + & + & + & + & + & + & - & + & + & - & + & + & + & + & + \\
\hline
\end{tabular}

Keterangan: TSIA (Triple Sugar Iron Agar): AS (Acid Slant), AB (Acid Butt), $\mathrm{H}_{2} \mathrm{~S}$ (Hydrogen Sulfide), SIM (Sulfide Indole Motility): S (Sulfide), I (Indole), M (Motility), SC (Simmon Citrate), MR (Methylen Red), Koa (Uji Koagulase), Glu (Glukosa), Man (Manitol), Lkt (Laktosa), Dex (Dextrosa), Skr (Sukrosa).

Selanjutnya 23 isolat bakteri tersebut diidentifikasi secara biokimia dengan menggunakan media TSIA, SIM, SCA, MR, uji koagulase, dan menggunakan uji gula-gula (glukosa, laktosa, manitol, dextrosa, dan sukrosa). Hasil uji biokimia, uji koagulase, dan uji gula-gula bakteri tersebut dapat dijelaskan pada tabel 2. 


\section{Pembahasan}

Pada uji koagulase 23 isolat menunjukkan hasil negatif dengan tidak terbentuknya gumpalan di sekitar tabung. Hasil identifikasi bakteri dengan uji biokimia terhadap 23 sampel menunjukan hasil uji TSIA pada isolat B1, B2, B3, B5, B6, B7, B8, B9, B10, T1, T7, T8, T10, T18, G5, G6, G7, G9, G10 dan G11 bakteri mampu memproduksi $\mathrm{H}_{2} \mathrm{~S}$ dan mampu memfermentasi laktosa dan glukosa. Pada isolat T3, T9, dan T11 menunjukkan bakteri mampu memproduksi $\mathrm{H}_{2} \mathrm{~S}$ serta hanya mampu memfermentasi glukosa. Hasil uji SIM 23 isolat menunjukkan $\mathrm{H}_{2} \mathrm{~S}$ positif, indol positif, dan motilitas negatif. Uji SCA menunjukan hasil positif dan uji MR positif. Identifikasi pada uji gula - gula menunjukkan B1, B2, B3, B5, B6, B7, B8, B9, B10, T1, T7, T8, T10, T18, G5, G6, G7, G9, G10 dan G11 mampu memfermentasi glukosa, laktosa, manitol, dextrosa, dan sukrosa sedangkan pada isolat T3, T9, dan T11 bakteri mampu memfermentasi glukosa, manitol, dextrosa, dan sukrosa. Hal ini sesuai dengan literatur menurut Carter and Cole (1990) yang menyatakan bahwa beberapa bakteri Streptococcus sp. mampu memfermentasi laktosa, manitol dan glukosa.

Berdasarkan hasil identifikasi bakteri dengan uji biokimia isolat $\mathrm{B} 1, \mathrm{~B} 2, \mathrm{~B} 3, \mathrm{~B} 5$, B6, B7, B8, B9, B10, T1, T7, T8, T10, T18, G5, G6, G7, G9, G10 dan G11 adalah bakteri Streptococcus sp. dengan kemungkinan spesies yaitu Streptococcus uberis dengan menunjukan zona hemolitik $\alpha$ pada Blood agar, serta mampu memfermentasi manitol, laktosa, glukosa, serta koagulase negatif (Carter et al., 1990). Sedangkan isolat T3, T9, dan T11 adalah bakteri Streptococcus sp. dengan kemungkinan spesies yaitu Streptococcus porcinus dengan menunjukan zona hemolitik $\beta$ pada Blood agar, serta mampu memfermentasi manitol dan glukosa namun tidak mampu memfermentasi laktosa (Carter et al., 1990).

Distribusi bakteri Streptococcus sp. pada saluran pernapasan babi penderita PRDC yang dibedakan berdasarkan kelompok umur yaitu pra sapih dan pasca sapih disajikan dalam tabel 3.

Tabel 3. Distribusi bakteri Streptococcus sp. pada saluran pernapasan babi penderita PRDC yang dibedakan berdasarkan kelompok umur

\begin{tabular}{lccc}
\hline & \multicolumn{2}{c}{ Infeksi bakteri } & Total \\
\cline { 2 - 3 } & Positif & Negatif & \\
\hline Umur babi & 13 & 3 & 16 \\
- Prasapih & 10 & 17 & 27 \\
- Pasca sapih & 23 & 20 & 43 \\
Total & & & \\
\hline
\end{tabular}

Pada tabel 3 diketahui bahwa jumlah sampel positif bakteri Streptococcus sp. pada babi pra sapih dan pasca sapih penderita PRDC yaitu sebanyak 23 sampel. Jumlah sampel positif pada babi prasapih sebanyak 13 sampel dan 3 sampel negatif. Sedangkan pada babi pasca sapih jumlah sampel positif sebanyak 10 sampel dan 17 sampel negatif. Dari data di atas menunjukkan bahwa jumlah babi pra sapih yang positif terinfeksi bakteri Streptococcus sp. lebih banyak dibandingkan pada babi pasca sapih. Data jumlah sampel positif Streptococcus sp. pada saluran pernapasan babi yang dianalisis dengan Chi-square menunjukkan nilai cukup signifikan yaitu $0.005(\mathrm{P}<0.05)$ yang berarti bahwa jumlah kejadian infeksi bakteri Streptococcus sp. pada babi prasapih lebih tinggi secara nyata dibandingkan dengan babi pasca sapih.

Streptococcus sp. merupakan bakteri flora normal yang terdapat pada saluran respirasi atas babi dan berpotensi patogen. 
Penyakit saluran pernapasan babi pada umumnya dipicu oleh banyak faktor, antara lain interaksi antara mikroorganisme infeksius dan beberapa faktor predisposisi antara lain sistem pertahanan inang, lingkungan dan stres (Hartel et al., 2004). Strain Streptococcus patogenik memiliki beberapa faktor virulensi seperti antigen karbohidrat dan protein spesifik, produksi toksin maupun enzim (Vecht et al., 1989). Streptococcus $\beta$ haemolitik grup A dapat mengeluarkan sejumlah eksoprotein ekstraselular aktif yang bekerja sebagai toksin sistemik atau sebagai enzim invasif lokal seperti hemolisin yaitu streptolisin O dan streptolisin S, streptokinase, DNAse, proteinase seperti nikotinamid adenin dinukleotidase (NADase), adenosin trifosfatase (ATPase), neuraminidase, fosfatase, hialuronidase, dan lipoproteinase. Selain itu dikeluarkan juga eksotoksin pirogenik (eritrogenik) A, B, dan C (Sari P., 2009). Streptococcuss sp. serotipe patogen memiliki faktor antifagositik Capsular Polysaccharide (CPS) sebagai faktor virulensi utama. Komponen dinding sel bakteri yaitu peptidoglikan serta asam teichoic dan lipoteichoic terlibat sebagai faktor virulensi, terutama yang terlibat dalam resistensi terhadap pembunuhan oleh sel fagositik, resistensi terhadap kationik antimikrobial peptida, dan / atau induksi inflamasi berlebihan. Beberapa protein seperti hemaglutinin, lipoprotein, muramidase-released protein (MRP), dan faktor ekstraseluler (EF) juga termasuk ke dalam faktor virulensi dari bakteri Streptococcus sp. serotipe patogen.

Jumlah kejadian infeksi bakteri Streptococcus sp. pada babi prasapih lebih tinggi secara nyata dibandingkan dengan babi pasca sapih. Jumlah sampel positif pada babi prasapih sebanyak 13 sampel sedangkan pada babi pasca sapih jumlah sampel positif sebanyak 10 sampel. Hasil ini sesuai dengan hasil penelitian Yeotaek Cheong et al (2017) yang menyatakan dari 214 sampel yang diperiksa babi dengan kelompok umur 3-7 minggu yang positive terinfeksi Streptococcus suis sebagai penyebab penyakit Porcine Respiratory Diasease Complex (PRDC) mencapai 70\%, kelompok umur 8 - 12 minggu mencapai $55 \%$, kelompok umur 13 - 16 minggu mencapai 53\%, sedangkan kelompok umur 17 - 26 minggu mencapai 51\%. Hal ini menandakan bahwa babi pra sapih lebih rentan terhadap infeksi Streptococcus sp.

Umur memiliki pengaruh terhadap kerentanan penyakit. Periode kritis dalam beternak babi adalah pada periode saat lahir hingga disapih. Menurut Sihombing (1997) anak babi yang disapih kurang dari empat minggu sangat mudah terkena stress dan penyakit akibat sistem kekebalan tubuh yang belum tumbuh secara optimal. Menurut Besung (2010) Anak babi yang baru lahir atau pra sapih sangat mudah terserang penyakit karena ketahanan tubuh anak babi yang masih rendah. Hal ini disebabkan karena belum sempurnanya sistem kekebalan tubuh, baik kekebalan tubuh spesifik maupun non spesifik. Anak babi yang baru lahir juga memiliki keterbatasan untuk menghasilkan antibody, keterbatasan ini berakibat tidak terjadinya inaktivasi agen bakteri yang masuk, sehinga bakteri dapat masuk ke saluran pernapasan dan menyebabkan gangguan penyakit. Pemusnahan agen bakteri di dalam tubuh babi yang memiliki antibody akan lebih cepat dibandingkan dengan yang tidak memiliki antibodi. Pelenyapan bakteri akan lebih dipercepat apabila dalam tubuh sudah terdapat antibodi yang spesifik ditujukan pada bakteri tersebut. Hal ini karena adanya antibodi mempermudah makrofag melakukan opsonisasi sehingga infeksi tidak berlangsung.

\section{SIMPULAN DAN SARAN}

\section{Simpulan}

Berdasarkan penelitian yang dilakukan, dapat disimpulkan bahwa ditemukan bakteri Streptococcus spp. pada saluran pernapasan babi penderita PRDC serta distribusi bakteri Streptococcus spp. pada babi pra sapih lebih banyak secara nyata dibandingkan dengan babi pasca sapih. 


\section{Saran}

Bagi peternak babi agar lebih memerhatikan sanitasi kandang, faktor higienisitas pakan, serta nutrisi pakan yang di berikan agar babi tidak semakin rentan terhadap infeksi berbagai macam penyakit khususnya penyakit saluran pernapasan. Masa laktasi sebaiknya dilakukan sesuai dengan anjuran agar anak babi memiliki maternal antibodi sehingga dapat memberikan daya tahan tubuh terhadap infeksi agen penyakit. Bagi penelitian selanjutnya perlu dilengkapi dengan uji voges proskauer, trehalose, sorbitol, salicin, raffinose, inulin, esculin, dan sodium hippurate untuk dapat menentukkan spesies Streptococcus lebih spesifik.

\section{UCAPAN TERIMAKASIH}

Penulis mengucapkan terimakasih kepada Laboratorium Bakteriologi dan Mikologi Veteriner Fakultas Kedokteran Hewan Universitas Udayana, serta semua pihak yang telah membantu proses penelitian ini.

\section{DAFTAR PUSTAKA}

Adi AAAM. 2014. Buku Ajar Patologi Veteriner Sistemik: Sistem Pernafasan. Udayana University Press. Denpasar.

Agustina KK, Wirata IW, Dharmayudha AAGO, Kardena IM, Dharmawan NS. 2016. Increasing farmer income by improved pig management systems. Buletin Vet. Udayana. 8(2): 122-127.

Baele M. 2001. The Gram-positive tonsillar and nasal flora of piglets before and after weaning. Journal of Applied Microbiology. 91: 997-1003.

Besung INK. 2010. Kejadian Kolibasilosis Pada Anak Babi. Majalah Ilmiah Peternakan. 13(1):1-12

Carter GR, and Cole JR. 1990. Diagnostic Procedures in Veterinary Bacteriology and Mycology. $5^{\text {th }}$ ed. Academic Press.
Cheong Y, C Oh, K Lee, and K Cho. 2016. Survey of porcine respiratory disease complex-associated pathogens among commercial pig farms in Korea via oral fluid method. Seoul. J Vet Sci, 18(3): 283-289

Del'Arco AE, JL Santos, PD Bevilacqua, JE Faria, and WV Guimarães. 2008. Swine infection by Streptococcus suis : a retrospective study. Arq. Bras. Med. Vet. Zootec. v.60, n.4, p.878-883

Dinas Peternakan Propinsi. 2018. Babi Landrace \& Semua Data Babi. Dinas Peternakan Propinsi Bali. Denpasar.

Halbur PG, 1997. Porcine respiratory disease complex. In: North Carolina Healthy Hogs Seminar. http://mark.asci.

ncsu.edu/HealthyHogs/book1997/halb ur2.htm

Hartel H, S.Nikunen, E.Neuvonen, R.Tanskanen, S.L. Kivela, P.Aho, T. Soveri, H.Saloniem. 2004. Viral and Bakterial Phathogens in Bovine Respiratory Disease in Finland.Acta Veterinaria Scandinavic.a (45):193200.

Ross RF. 1999. Mycoplasmal pneumonia of swine. In: Diseases of Swine, ed. D. J. Taylor, Iowa State University Press, Ames, Iowa, pp. 49 5-501.

Sihombing DT. 1997. Ilmu Ternak Babi. Gadjah Mada University Press: Yogyakarta. Hal.527

Toelle NN, and Lenda V. 2014. Identifikasi dan Karakteristik Staphylociccus sp. dan Streptococcus sp. dari Infeksi Ovarium Pada Ayam Petelur Komersial. Jurnal Ilmu Ternak. Vol. 1, NO. 7,32 - 37

Opriessnig T, LG Gime'nez-Lirola, and PG Halbur. 2011. Polymicrobial respiratory disease in pigs. USA. Department of Veterinary Diagnostic and Production Animal Medicine, College of Veterinary Medicine. Iowa State University. 